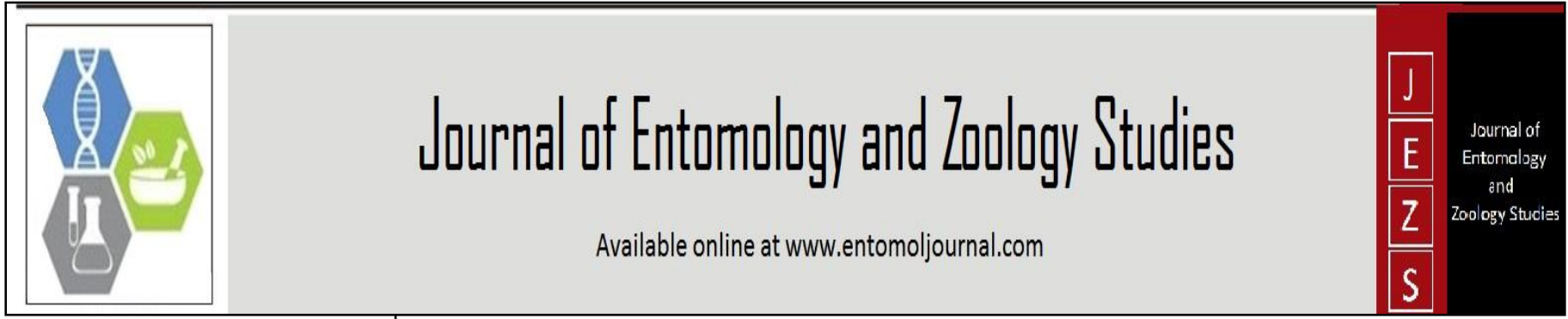

E-ISSN: 2320-7078

P-ISSN: 2349-6800

www.entomoljournal.com

JEZS 2021; 9(1): 1104-1106

(C) $2021 \mathrm{JEZS}$

Received: 30-10-2020

Accepted: 28-12-2020

\section{G Gokila}

Department of Agricultural

Entomology, Agricultural

College and Research Institute,

Tamil Nadu Agricultural

University, Madurai,

Tamil Nadu, India

K Premalatha

Department of Agricultural

Entomology, Tamil Nadu

Agricultural University,

Coimbatore, Tamil Nadu, India

\section{Chinniah}

Department of Agricultural Entomology, Agricultural

College and Research Institute,

Tamil Nadu Agricultural

University, Madurai,

Tamil Nadu, India

\section{Shanthi}

Department of Agricultural

Entomology, Agricultural

College and Research Institute,

Tamil Nadu Agricultural

University, Madurai,

Tamil Nadu, India

\section{R Nalini}

Department of Agricultural

Entomology, Agricultural

College and Research Institute,

Tamil Nadu Agricultural

University, Kudumiyanmalai,

Tamil Nadu, India

\section{S Vellaikumar}

Department of Biotechnology, Agricultural College and

Research Institute,

Tamil Nadu Agricultural

University, Madurai,

Tamil Nadu, India

Corresponding Author:

G Gokila

Department of Agricultural

Entomology, Agricultural

College and Research Institute,

Tamil Nadu Agricultural

University, Madurai,

Tamil Nadu, India

\section{Field assessment of elicitors on rice leaf folder, Cnaphalocrocis medinalis (Guenee) (Pyralidae: Lepidoptera) and coccinellid population in rice ecosystem}

\section{G Gokila, K Premalatha, C Chinniah, M Shanthi, R Nalini and S Vellaikumar}

DOI: https://doi.org/10.22271/j.ento.2021.v9.i10.8289

\section{Abstract}

The present investigation was carried out to estimate the efficacy of different elicitors on rice leaf folder, Cnaphalocrocis medinalis (Guenee) and coccinellid predators under field conditions at Puthuthamaraipatty village and AC\&RI, Madurai. Among the different elicitors tested, Methyl salicylate @ $10 \mathrm{mM}$ conc. recorded the lowest per cent leaf damage of 3.38 and 4.16 in field trial I and field trial II respectively. The per cent reduction of leaf damage over untreated check in field trial I was 74.37 and 75.08 in field trial II, followed by salicylic acid @ $10 \mathrm{mM}$ conc. with 68.12 and 68.79 in field trial I and field trial II. Methyl salicylate @ 10 mM conc. attracted more population of coccinellids, 0.99/sweep and 1.15/sweep in field trial I and field trial II, respectively, followed by salicylic acid @ $10 \mathrm{mM}$ conc. which recorded the mean coccinellid population of $0.83 /$ sweep in field trial I and $0.93 /$ sweep in field trial II.

Keywords: rice leaf folder, $C$. medinalis, coccinellids, elicitors, herbivore induced plant volatiles

\section{Introduction}

Crop plants are incessantly challenged by a wide range of abiotic and biotic stresses throughout their life cycle ${ }^{[13]}$. Constitutive and induced resistance are the two type of resistance which are manifested by the crop plants in opposition to herbivore attack. Induced defense is activated by elicitors present in the herbivore oviposition fluids or oral secretions (OS) that provoke plant defense response ${ }^{[9]}$. During herbivory attack, the defense response elicitors are released, which induce the volatile emission to attract predators and parasitoids of the herbivore ${ }^{[11]}$. The phytohormones as elicitors are most often associated with mediating plant responses to insects viz., Jasmonic acid (JA), Salicylic acid (SA) and Ethylene (ET) ${ }^{[16]}$. Methyl salicylate is an elicitor which immediately induces plant defence ${ }^{[3]}$.

Rice (Oryza sativa L.) is the most important cereal crop grown in many Asian countries. Among the several insect pests of rice, rice leaf folder is an important pest, which causes severe damage in rice crop. In leaf folder epidemic condition, 30-80\% yield loss would have occurred. One unit increase in C. medinalis infestation leads to $14 \%$ and $1.46 \%$ yield loss respectively in summer and wet conditions ${ }^{[1]}$. Natural enemies that are present in the rice fields play a significant role in reducing the insect pest population and yield loss ${ }^{[14]}$.

With this background the present study was carried out to estimate the efficacy of three different elicitors as attractants towards predators of rice leaf folder under field conditions. Thus, by testing the field efficacy of elicitors, they can be used as a potential semiochemical for the sustainable management of $C$. medinalis on rice.

\section{Materials and Methods}

The experiment was laid out in a farmer's field at Puthuthamaraipatty (Field trial I) and in the wet land, Agricultural College and Research Institute, Madurai (Field trial II) during Rabi 2019-2020.

\subsection{Field study}

The plot size was $5 \times 4 \mathrm{~m}^{2}$. Rice variety ASD 16 was chosen for this investigation. Three different elicitors viz., Salicylic acid (SA), Methyl salicylate (MeSA) and Ethephon (ET) were 
applied as a foliar spray at specified concentrations on rice crop on $50^{\text {th }}$ and $70^{\text {th }}$ days after transplanting. The untreated check plot was sprayed with water alone, each treatment was replicated thrice. One meter on each side of the row and three rows between the plots were left untreated as a buffer zone.

$\mathrm{T}_{1}$ - Methyl salicylate @1mM conc.

$\mathrm{T}_{2}$-Methyl salicylate@10mM conc.

$\mathrm{T}_{3}$ - Salicylic acid @1mM conc.

$\mathrm{T}_{4}$ - Salicylic acid @ $10 \mathrm{mM}$ conc.

$\mathrm{T}_{5}$ - Ethephon@0.3mM conc.

$\mathrm{T}_{6}$ - Ethephon@1mM conc.

$\mathrm{T}_{7}$ - Untreated check

The leaf folder damage and coccinellid population were recorded before and after treatment. Observations on percent infestation of leaf folder were recorded before and after spraying and the coccinellid population was assessed on 0,1 , 3,5 and 7 days after application of elicitors.

The leaf folder damage was recorded from five hills selected at random per plot and the percent leaf damage was computed adopting the formula:

Number of leaves showing scrapping
symptom per hill

Grubs and adults of coccinellids were collected using a sweep net. The population of the natural enemies is expressed as numbers per sweep.

\subsection{Statistical analysis}

The field trial was laid out in a Randomized Block Design (RBD). The data on percent leaf damage was converted into corresponding arc sine values and the coccinellid population was transformed into $\sqrt{ } \mathrm{X}$. The mean values were separated by Duncan's multiple range test (DMRT) to compare the means [4].

\section{Results and Discussion}

\subsection{Per cent leaf damage by rice leaf folder, $C$. medinalis}

The field investigation on the impact of different elicitors on leaf folder revealed that incase of Methyl Salicylate @ 10 $\mathrm{mM}$ conc. the percent leaf folder damage was significantly less in both the field trials. The percent leaf folder damage was 4.23 and 2.53 in MeSA @ $10 \mathrm{mM}$ conc. at field trial I after first and second spray respectively. The cumulative mean on per cent leaf damage was 3.38. Similar results were observed in field trial II also with a cumulative mean of 4.16 and the per cent leaf damage was 4.95 and 3.37 after the first and second spray respectively. The percent reduction over untreated check was as high as 74.37 in field trial I and while 75.08 in field trial II. The next in the order of efficacy is Salicylic acid @10 mM conc. With the reduction of 68.12 and 68.79 in field trial I and field trial II, respectively (Table 1). Similar results were also obtained by Kalaivani et al. (2018) ${ }^{[10]}$ who proved that MeSA application in rice significantly reduced the leaf damage by leaf folder. In the rice ecosystem, resistance to leaf folders was mediated by SA ${ }^{\text {[17] }}$. Indhumathi et al. (2019) ${ }^{[5]}$ observed that MeSA treated rice leaves were less preferred by rice leaf folder, $C$. medinalis. Arabidopsis thaliana treated with Salicylic acid reduced the feeding efficiency of Spodotera exigua H. more than $50 \%$ after treatment ${ }^{[2]}$.

\subsection{Coccinellid population}

The impact of the elicitors was exposed by observing the attractiveness of the coccinellid towards the treated plots. The relative performance of the elicitors revealed that MeSA @ 10 $\mathrm{mM}$ conc. had recorded the highest coccinellid population of $1.11 /$ sweep and $0.86 /$ sweep in the first and second spray of field trial I with the cumulative mean of $0.99 /$ sweep. In field trial II, the coccinellid population was $1.11 / \mathrm{sweep}$ and $1.19 /$ sweep in first and second spray respectively. The cumulative mean of coccinellid population in field trial II was $1.15 /$ sweep, followed by salicylic acid @ $10 \mathrm{Mm}$ conc. attracted more coccinellids with the cumulative mean of 0.83 sweep in field trial I and 0.93 in field trial II. In the untreated check plot, the recorded coccinellid population was $0.22 /$ sweep and $0.27 /$ sweep in field trial I and field trial II respectively (Table 1). Ishiwari et al. (2007) ${ }^{[6]}$ reported that MeSA is a common HIPVs and attracts natural enemies of herbivores. The HIPVs recognized by predators/parasitoids depend on herbivores and also the chemical blends help the natural enemies to recognize or discriminate the chemical cues from non-host. MeSA also one of the important HIPVs among the reported HIPVs ${ }^{[15]}$. The sticky traps baited with MeSA found to attract predators of Chrysopidae, Miridae, Geocoridae, Anthocoridae, Syrphidae and Coccinellidae ${ }^{[7]}$. MeSA was reported to act as an attractant for Erigonidium graminicolum and Orius similis in the cotton ecosystem ${ }^{[18]}$. Orientation behaviour of the coccinellid was higher towards MeSA treated rice leaves ${ }^{[5]}$. Not only the predators, the parasitoids like Mymaridae and Encyrtidae were also attracted by MeSA ${ }^{[8]}$. Mahmoud and Mahfouz (2015) ${ }^{[12]}$ reported that application of salicylic acid @ 200 mg/l deterred herbivory from wheat and increased foraging activity of parasitoids and predators.

Table 1: Effect of different elicitors on leaf folder damage and Coccinellid population in rice ecosystem

\begin{tabular}{|c|c|c|c|c|c|c|c|c|c|c|c|c|c|c|}
\hline \multirow{2}{*}{\multicolumn{8}{|c|}{ Variety: ASD 16}} & \multicolumn{7}{|c|}{ Season: Rabi 2019-2020 } \\
\hline & & & & & & & & & & & ield Trial II & & & \\
\hline \multirow[b]{2}{*}{ Treatments } & \multicolumn{4}{|c|}{ age } & \multicolumn{3}{|c|}{$\begin{array}{c}\text { Coccinellid population } \\
\text { (Nos/sweep) }\end{array}$} & \multicolumn{4}{|c|}{ Per cent leaf damage } & \multicolumn{3}{|c|}{$\begin{array}{c}\text { Coccinellid population } \\
\text { (Nos/sweep) }\end{array}$} \\
\hline & $\begin{array}{c}\text { Mean } \\
\text { (after } \\
\text { first } \\
\text { spray) }\end{array}$ & $\begin{array}{l}\text { Mean } \\
\text { (after } \\
\text { second } \\
\text { spray) }\end{array}$ & $\begin{array}{c}\text { Cumulative } \\
\text { mean }\end{array}$ & $\begin{array}{l}\text { Per cent } \\
\text { reduction } \\
\text { over } \\
\text { untreated } \\
\text { check }\end{array}$ & \begin{tabular}{|c} 
Mean \\
(after \\
first \\
spray)
\end{tabular} & $\begin{array}{c}\text { Mean } \\
\text { (after } \\
\text { second } \\
\text { spray) }\end{array}$ & $\begin{array}{c}\text { Cumulative } \\
\text { mean }\end{array}$ & $\begin{array}{l}\text { Mean } \\
\text { (after } \\
\text { first } \\
\text { spray) }\end{array}$ & $\begin{array}{c}\text { Mean } \\
\text { (after } \\
\text { second } \\
\text { spray) }\end{array}$ & $\begin{array}{c}\text { Cumulative } \\
\text { mean }\end{array}$ & \begin{tabular}{|c|} 
Per cent \\
reduction \\
over \\
untreated \\
check
\end{tabular} & $\begin{array}{c}\text { Mean } \\
\text { (after } \\
\text { first } \\
\text { spray) }\end{array}$ & $\begin{array}{c}\text { Mean } \\
\text { (after } \\
\text { second } \\
\text { spray) }\end{array}$ & $\begin{array}{c}\text { Cumulative } \\
\text { mean }\end{array}$ \\
\hline $\mathrm{T}_{1}$ & $\begin{array}{c}7.10 \\
(15.45)^{\mathrm{bc}}\end{array}$ & $\begin{array}{c}4.58 \\
(12.35)^{\mathrm{cd}}\end{array}$ & $\begin{array}{c}5.84 \\
(13.98)^{\mathrm{c}}\end{array}$ & 55.72 & $\begin{array}{c}0.61 \\
(0.78)^{\mathrm{c}}\end{array}$ & $\begin{array}{c}0.50 \\
(0.71)^{\mathrm{b}}\end{array}$ & $\begin{array}{c}0.56 \\
(0.75)^{\mathrm{d}}\end{array}$ & $\begin{array}{c}7.27 \\
(15.64)^{\mathrm{bc}}\end{array}$ & $\begin{array}{c}6.06 \\
(14.25)^{\mathrm{bc}}\end{array}$ & $\begin{array}{c}6.66 \\
(14.96)^{\mathrm{cd}}\end{array}$ & 60.11 & \begin{tabular}{|c|}
0.69 \\
$(0.83)^{\mathrm{bc}}$
\end{tabular} & $\begin{array}{c}0.72 \\
(0.85)^{\mathrm{c}}\end{array}$ & $\begin{array}{c}0.71 \\
(0.84)^{\mathrm{c}}\end{array}$ \\
\hline $\mathrm{T}_{2}$ & $\begin{array}{c}4.23 \\
(11.87)^{\mathrm{a}}\end{array}$ & $\begin{array}{c}2.53 \\
(9.15)^{\mathrm{a}}\end{array}$ & $\begin{array}{c}3.38 \\
(10.59)^{\mathrm{a}}\end{array}$ & 74.37 & $\begin{array}{c}1.11 \\
(1.05)^{\mathrm{a}}\end{array}$ & $\begin{array}{c}0.86 \\
(0.93)^{\mathrm{a}} \\
\end{array}$ & $\begin{array}{c}0.99 \\
(0.99)^{\mathrm{a}}\end{array}$ & $\begin{array}{c}4.95 \\
(12.86)^{\mathrm{a}}\end{array}$ & $\begin{array}{c}3.37 \\
(10.58)^{\mathrm{a}}\end{array}$ & $\begin{array}{c}4.16 \\
(11.77)^{\mathrm{a}}\end{array}$ & 75.08 & $\begin{array}{c}1.11 \\
(1.05)^{\mathrm{a}}\end{array}$ & $\begin{array}{c}1.19 \\
(1.09)^{\mathrm{a}}\end{array}$ & $\begin{array}{c}1.15 \\
(1.07)^{\mathrm{a}}\end{array}$ \\
\hline $\mathrm{T}_{3}$ & $\begin{array}{c}6.84 \\
(15.17)^{\mathrm{bc}}\end{array}$ & $\begin{array}{c}5.55 \\
(13.63)^{\mathrm{de}}\end{array}$ & $\begin{array}{c}6.20 \\
(14.42)^{\mathrm{cd}}\end{array}$ & 52.98 & $\begin{array}{c}0.47 \\
(0.69)^{\mathrm{d}}\end{array}$ & $\begin{array}{c}0.44 \\
(0.67)^{\mathrm{b}}\end{array}$ & $\begin{array}{c}0.46 \\
(0.68)^{\mathrm{d}}\end{array}$ & $\begin{array}{c}7.63 \\
(16.03)^{\mathrm{c}}\end{array}$ & $\begin{array}{c}7.08 \\
(15.44)^{\mathrm{c}}\end{array}$ & $\begin{array}{c}7.35 \\
(15.74)^{\mathrm{d}}\end{array}$ & 55.97 & $\begin{array}{c}0.58 \\
(0.76)^{\mathrm{c}}\end{array}$ & $\begin{array}{c}0.53 \\
(0.73)^{\mathrm{d}} \\
\end{array}$ & $\begin{array}{c}0.56 \\
(0.75)^{\mathrm{d}}\end{array}$ \\
\hline $\mathrm{T}_{4}$ & 4.95 & 3.45 & 4.20 & 68.12 & 0.92 & 0.75 & 0.83 & 5.51 & 4.92 & 5.21 & 68.79 & 0.92 & 0.94 & 0.93 \\
\hline
\end{tabular}




\begin{tabular}{|c|c|c|c|c|c|c|c|c|c|c|c|c|c|c|}
\hline & $(12.86)^{\mathrm{a}}$ & $(10.71)^{\mathrm{ab}}$ & $(11.83)^{\mathrm{ab}}$ & & $(0.96)^{\mathrm{b}}$ & $(0.87)^{\mathrm{a}}$ & $(0.91)^{\mathrm{b}}$ & $(13.57)^{\mathrm{ab}}$ & $(12.82)^{\mathrm{b}}$ & $(13.20)^{\mathrm{b}}$ & & $(0.96)^{\mathrm{ab}}$ & $(0.97)^{\mathrm{b}}$ & $(0.96)^{\mathrm{b}}$ \\
\hline $\mathrm{T}_{5}$ & $\begin{array}{c}8.26 \\
(16.70)^{\mathrm{c}} \\
\end{array}$ & \begin{tabular}{|c|}
6.03 \\
$(14.22)^{\mathrm{e}}$ \\
\end{tabular} & $\begin{array}{c}7.15 \\
(15.51)^{d} \\
\end{array}$ & 45.80 & $\begin{array}{c}0.42 \\
(0.65)^{\mathrm{d}}\end{array}$ & $\begin{array}{c}0.28 \\
(0.53)^{\mathrm{c}}\end{array}$ & $\begin{array}{c}0.35 \\
(0.59)^{\mathrm{e}} \\
\end{array}$ & $\begin{array}{c}8.13 \\
(16.57)^{\mathrm{c}} \\
\end{array}$ & $\begin{array}{c}7.48 \\
(15.87)^{\mathrm{c}} \\
\end{array}$ & $\begin{array}{c}7.80 \\
(16.22)^{d} \\
\end{array}$ & 53.29 & \begin{tabular}{|c|}
0.33 \\
$(0.58)^{\mathrm{d}}$ \\
\end{tabular} & $\begin{array}{c}0.47 \\
(0.69)^{\mathrm{d}} \\
\end{array}$ & $\begin{array}{c}0.40 \\
(0.63)^{\mathrm{e}} \\
\end{array}$ \\
\hline $\mathrm{T}_{6}$ & $\begin{array}{c}5.51 \\
(13.57)^{\mathrm{ab}}\end{array}$ & $\begin{array}{c}3.72 \\
(11.12)^{\mathrm{bc}}\end{array}$ & $\begin{array}{c}4.61 \\
(12.40)^{\mathrm{b}}\end{array}$ & 65.01 & $\begin{array}{c}0.78 \\
(0.88)^{\mathrm{b}}\end{array}$ & $\begin{array}{c}0.56 \\
(0.75)^{\mathrm{b}}\end{array}$ & $\begin{array}{c}0.67 \\
(0.82)^{\mathrm{c}}\end{array}$ & $\begin{array}{c}6.13 \\
(14.33)^{\mathrm{ac}}\end{array}$ & $\begin{array}{c}5.31 \\
(13.33)^{b}\end{array}$ & $\begin{array}{c}5.72 \\
(13.84)^{\mathrm{bc}}\end{array}$ & 65.75 & \begin{tabular}{|c|}
0.78 \\
$(0.88)^{\mathrm{bc}}$
\end{tabular} & $\begin{array}{c}0.78 \\
(0.88)^{\mathrm{bc}}\end{array}$ & $\begin{array}{c}0.78 \\
(0.88)^{\mathrm{c}}\end{array}$ \\
\hline $\mathrm{T}_{7}$ & $\begin{array}{c}13.09 \\
(21.21)^{\mathrm{d}}\end{array}$ & $\begin{array}{c}13.28 \\
(21.37)^{\mathrm{f}} \\
\end{array}$ & $\begin{array}{c}13.18 \\
(21.29)^{\mathrm{e}}\end{array}$ & & $\begin{array}{c}0.22 \\
(0.47)^{\mathrm{e}}\end{array}$ & $\begin{array}{c}0.22 \\
(0.47)^{\mathrm{c}}\end{array}$ & $\begin{array}{c}0.22 \\
(0.47)^{\mathrm{f}}\end{array}$ & $\begin{array}{c}16.42 \\
(23.90)^{\mathrm{d}} \\
\end{array}$ & $\begin{array}{c}16.99 \\
(24.34)^{\mathrm{d}} \\
\end{array}$ & $\begin{array}{c}16.71 \\
(24.12)^{\mathrm{e}}\end{array}$ & & \begin{tabular}{|c|}
0.28 \\
$(0.53)^{\mathrm{d}}$
\end{tabular} & $\begin{array}{c}0.25 \\
(0.50)^{\mathrm{e}} \\
\end{array}$ & $\begin{array}{c}0.27 \\
(0.51)^{\mathrm{f}}\end{array}$ \\
\hline SEd & 1.00 & 0.75 & 0.66 & & 0.04 & 0.04 & 0.03 & 1.02 & 0.82 & 0.58 & & 0.06 & 0.04 & 0.03 \\
\hline $\mathrm{CD}(0.05)$ & 2.19 & 1.62 & 1.43 & & 0.08 & 0.09 & 0.07 & 2.23 & 1.80 & 1.27 & & 0.12 & 0.09 & 0.07 \\
\hline $\mathrm{CV} \%$ & 8.07 & 6.92 & 5.67 & & 5.78 & 7.43 & 5.44 & 7.79 & 6.64 & 4.57 & & 8.74 & 6.46 & 4.95 \\
\hline
\end{tabular}

Mean of three replications.

Each replication is a mean of five observations per plot and figures in parentheses are arc sine transformed values in percent leaf damage.

Each replication is a mean of three observations of 1,3,5 and 7 days after spraying per plot and figures in parentheses are square root transformed values in coccinellid population.

In the column, means followed by same letter are not significantly different by DMRT at $\mathrm{P}=0.05$.

$\mathrm{T}_{1}$ - Methyl salicylate @ 1mM conc.; $\mathrm{T}_{2}$-Methyl salicylate @ 10mM conc.; $\mathrm{T}_{3}$ - Salicylic acid @ 1mM conc.; $\mathrm{T}_{4}$ - Salicylic acid @ $10 \mathrm{mM}$ conc.; T5- Ethephon@ 0.3mM conc.; T6- Ethephon @ 1mM conc.; T7- Untreated check.

\section{Conclusion}

From this investigation it is evident that among the different elicitors tested, Methyl salicylate @ $10 \mathrm{mM}$ conc. significantly reduced the survival rate of leaf folder, apart from the per cent leaf damage in addition this attracted more population of coccinellid predators compared to other treatments.

\section{References}

1. Baby Rani W, Amutha R, Muthulakshmi S, Indira K, Mareeswari P. Diversity of Rice Leaf Folders and Their Natural Enemies. Research Journal of Agriculture and Biological Sciences 2007;3(5):394-397.

2. Cipollini D, Enright S, Traw M, Bergelson J. Salicylic acid inhibits jasmonic acid induced resistance of Arabidopsis thaliana to Spodoptera exigua. Molecular Ecology 2004;13(6):1643-1653.

3. Conboy NJA, Daniel TM, George D, Ormerod A, Edwards M, Donohoe $\mathrm{P}$ et al. Volatile Organic Compounds as Insect Repellents and Plant Elicitors: An Integrated Pest Management (IPM) Strategy for Glasshouse Whitefly (Trialeurodes vaporariorum). Journal of Chemical Ecology 2020;46:1090-1104.

4. Gomez KA, Gomez AA. Statistical procedures for agricultural research. Edn 2, John Wiley and Sons, New York 1984, 680.

5. Indhumathi J, Muthukrishnan $\mathrm{N}$, Durairaj $\mathrm{C}$, Thavaprakaash N, Soundararajan RP. Effect of Methyl Salicylate on Rice Leaffolder Cnaphalocrocis medinalis (Guenee), Parasitoid Xanthopimpla flavolineata (Cameron) and Predator Micraspis sp. Madras Agricultural Journal 2019;102(1-3):74-79.

6. Ishiwari H, Suzuki T, Maeda T. Essential Compounds in Herbivore-Induced Plant Volatiles that Attract the Predatory Mite Neoseiulus womersleyi. Journal of Chemical Ecology 2007;33(9):1670-1681.

7. James DG. Field evaluation of herbivore-induced plant volatiles as attractants for beneficial insects: methyl salicylate and the green lacewing, Chrysopa nigricornis. Journal of Chemical Ecology 2003;29(7):1601-1609.

8. James DG, Grasswitz TR. Synthetic herbivore-induced plant volatiles increase field captures of parasitic wasps. Bio Control 2005;50:871-880.

9. Iida J, Desaki Y, Hata K, Uemura T, Yasuno A, Islam M, et al. Tetranins: new putative spider mite elicitors of host plant defense. New Phytologist 2019;224:875-885.

10. Kalaivani K, Kalaiselvi MM, Senthil-Nathan S. Effect of Methyl Salicylate (MeSA) induced changes in rice plant (Oryza sativa) that affect growth and development of the rice leaffolder, Cnaphalocrocis medinalis. Physiological and Molecular Plant Pathology 2018;101:116-126.

11. Mattiacci L, Dicke M, Posthumus MA. $\beta$-Glucosidase: An elicitor of herbivore-induced plant odour that attracts host-searching parasitic wasps. Plant Biology 1995;92:2036-2040.

12. Mahmoud MF, Mahfouz HM. Effects of salicylic acid elicitor against aphids on wheat and detection of infestation using infrared thermal imaging technique in Ismailia, Egypt. Pestic. Phytomed (Belgrade) 2015;30(2):91-97.

13. Mithofer A, Boland W. Plant defense against herbivores: Chemical Aspects. Annual Review of Plant Biology 2012;63(1):431-450.

14. Moses S, Kishor DR, Misra AK, Ahmad A. Identification and Quantification of Major Insect Pests of Rice and Their Natural Enemies. Current Journal of Applied Science and Technology 2019;32(2):1-10.

15. Ozawa R, Shimoda T, Kawaguchi M, Arimura G, Horiuchi J, Nishioka $\mathrm{T}$ et al. Lotus japonicus Infested with Herbivorous Mites Emits Volatile Compounds That Attract Predatory Mites. Journal of Plant Research 2000;113(4):427-433.

16. Penaflor MFGV, Bento JMS. Herbivore-Induced Plant Volatiles to Enhance Biological Control in Agriculture. Neotrop entomol 2013;42:331-343.

17. Wang X, Hu L, Zhou G, Cheng J, Lou Y. Salicylic acid and ethylene signaling pathways are involved in production of rice trypsin proteinase inhibitors induced by the leaf folder Cnaphalocrocis medinalis (Guenee). Chinese science bulletin 2011;56(22):2351-2358.

18. Yu H, Zhang Y, Wu K, Gao XW, Guo YY. Field-Testing of Synthetic Herbivore-Induced Plant Volatiles as Attractants for Beneficial Insects. Environmental Entomology 2008;37(6):1410-1415. 